ISSN: $1412-4734$

E-ISSN: 2407-8646

Volume 18, Number 2, 2018

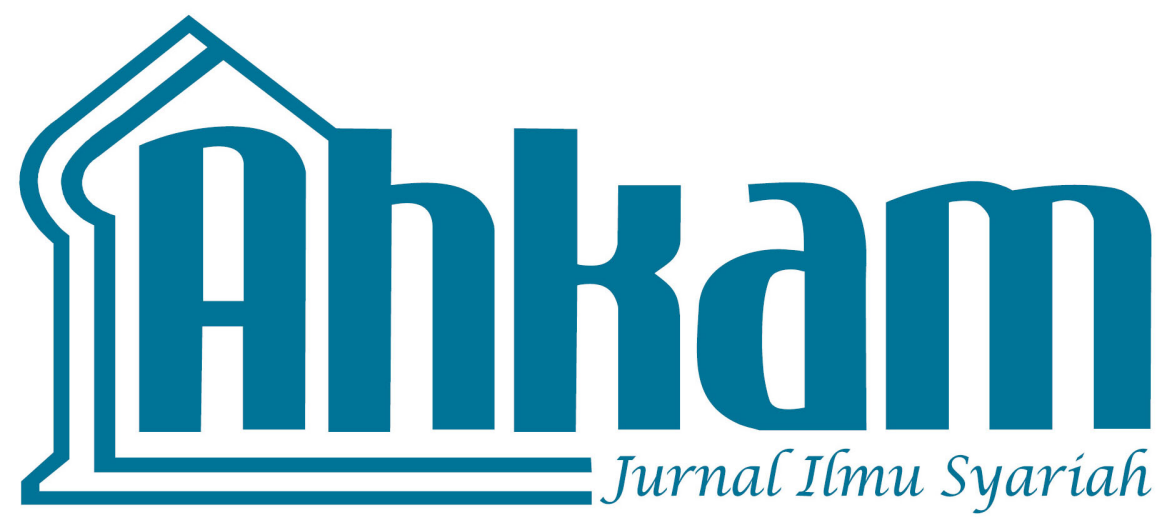

* Arifuddin Muda Harahap

Rules on Wage Standard to Improve Workers' Living Needs in the Perspective of Maqasid Al-Shari'ah

* M. IkHsan TanggoK

Circumcision Law in Christianity and Islam

* Abdul Rohman Zulfikar Alfaroug \& Nurhasanah The Positivisation of National Sharia Board Fatwa About Mudaraba into Financial Service Authority Regulation

* Muhamad Isna Wahyudi

Women Dealing With the Law in Religious Courts

* Arif Hidayatullah \& Anita Priantina

Toward Zakat Management Integration in Indonesia: Problems and Solution

* Muhammad Adil dan Muhamad Harun

Fiqh Melayu Nusantara in the Palembang Darussalam Sultanate Period

* Sugiri Permana

Implications of Hazairin and Munawir Sjadzali Thoughts in Establishment of Islamic Inheritance in Indonesia 


\section{Mhliam}

Volume 18, Number 2, 2018

\section{EDITOR-IN-CHIEF}

Khamami Zada

\section{EDITORS}

Fathudin

Maman R Hakim

Windy Triana

Nur Hidayah

Ahmad Bahtiar

\section{INTERNATIONAL EDITORIAL BOARD}

Tim Lindsey (University of Melbourne Australia)

Nadirsyah Hosen (Monash University Australia)

Ahmad Hidayat Buang (Universiti Malaya Malaysia)

Raihanah Azahari (University Malay Malaysia)

Mark Elwen Cammack (Southwestern University)

Razeen Sappideen (University of Western Sydney)

Carolyn Sappideen (University of Western Sydney)

Nik Ahmad Kamal bin Nik Mahmod (International Islamic Universiti Malaysia)

Ahmad Tholabi Kharlie (UIN Syarif Hidayatullah Jakarta)

Muhammad Atho Mudzhar (UIN Syarif Hidayatullah Jakarta)

Masykuri Abdillah (UIN Syarif Hidayatullah Jakarta)

Muhammad Amin Suma (UIN Syarif Hidayatullah Jakarta)

M. Arsykal Salim GP (UIN Syarif Hidayatullah Jakarta)

Asep Saepudin Jahar (UIN Syarif Hidayatullah Jakarta)

ASSISTANT TO THE EDITORS

Kamal F. Musa

Erwin Hikmatiar

ENGLISH LANGUAGE ADVISOR

Bradley Holland

Umi Kulsum

ARABIC LANGUAGE ADVISOR

Amany Burhanudin Lubis

AHKAM has been accredited based on the determination of Director General of Research Reinforcement and Development, Research, and Technology Ministry of Higher Education of Republic of Indonesia, No. 36/a/E/KPT/2016 (valid until 2021). 
AHKAM Jurnal Ilmu Syariah (ISSN: 1412-4734) is a periodical scientific journal published by Faculty of Sharia and Law of Syarif Hidayatullah State Islamic University Jakarta in collaboration with Indonesian Scientist and Sharia Scholar Association (HISSI). This journal specifically examines the science of sharia and obtains to present various results of current and eminence scientific research. The administrators receive articles as contributions Sharia and Islamic law disciplines from scientists, scholars, professionals, and researchers to be published and disseminated.

\section{EDITORIAL OFFICE:}

Fakultas Syariah dan Hukum UIN Syarif Hidayatullah Jakarta

Jl. Ir. H. Juanda 95 Ciputat, Jakarta 15412

Telp. (+62-21) 74711537, Faks. (+62-21) 7491821

Website: http://journal.uinjkt.ac.id/index.php/ahkam/index

E-mail: Jurnal.ahkam@uinjkt.ac.id 


\section{TABle of Contents}

251 Arifuddin Muda Harahap

Rules on Wage Standard to Improve Workers' Living Needs in the Perspective of Maqasid Al-Shari'ah

265 M. IkHSAN TANGgOK

Circumcision Law in Christianity and Islam

285 Abdul Rohman Zulfikar Alfaroug \& Nurhasanah The Positivisation of National Sharia Board Fatwa About Mudaraba into Financial Service Authority Regulation

305 Muhamad Isna Wahyudi

Women Dealing With the Law in Religious Courts

321 Arif Hidayatullah \& Anita Priantina

Toward Zakat Management Integration in Indonesia:

Problems and Solution

347 Muhammad Adil \& Muhamad Harun

Figh Melayu Nusantara in the Palembang Darussalam Sultanate Period 
375 Sugiri Permana

Implications of Hazairin and Munawir Sjadzali Thoughts in Establishment of Islamic Inheritance in Indonesia

395 RifQi QOWIyul ImAn

The Competence of Religious Court in Indonesia and

Syahadah Istifadhah (Testimonium De Auditu) in Case of Itsbat Waqf

417 Mustapa Khamal Rokan \& Kama Rusdiana Configuration of Costomary Law Related to Economy (Economic Adat Law Study in North Sumatera, Indonesia)

433 Yayan Sopyan \& Muhammad Shofwan Nidzami Nyabek Toloh Marriage Proposal Tradition in Madurese Culture: A Review of The Sociology of Islamic Law

453 Nuryani \& M. Musyafa

Linguistic Review on Marriage Age Regulation

463 Wetria Fauzi

Regulation of Sharia Insurance After the Enactment of Law No. 40 of 2014 Concerning Insurance 


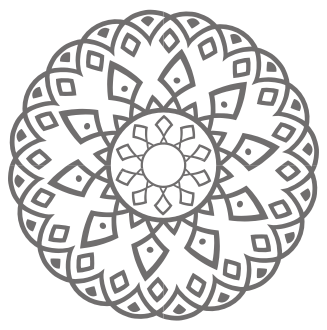

\title{
Linguistic Review on Marriage Age Regulation
}

\author{
Nuryani \& M. Musyafa'
}

\begin{abstract}
Abstrak: Studi ini menemukan bahwa UU Perkawinan Indonesia, khususnya pada bagian usia pernikahan, masih mengandung ambiguitas dalam hal bahasa. Hal ini mengarah pada kesenjangan dalam hukum sehingga berpotensi pada pelanggaran hukum. Dinyatakan dalam Kompilasi Hukum Islam, pasangan yang belum mencapai usia dua puluh tahun harus mendapatkan persetujuan dari kedua orangtua untuk menikah. Berdasarkan ketentuan ini, setiap pasangan, yang di bawah umur, dapat menikah selama mereka mendapatkan persetujuan orang tua mereka. Praktik ini tidak dianggap sebagai pelanggaran hukum sehingga pihak yang terlibat tidak dapat dihukum. Untuk itu, penulis berpendapat bahwa perlunya untuk meninjau hukum perkawinan untuk mencegah praktik perkawinan di bawah umur.
\end{abstract}

Kata kunci: ambiguitas, usia menikah, linguistik 
Abstract: This study finds that the Indonesian Marriage Law, especially in the section about the age of marriage, still contains the ambiguity in terms of the language. This leads to the gaps in the law that can potentially lead to the violation of the law. It is stated in the Compilation of Islamic Law that the couple who have not reached the age of twenty should obtain a consent from both parents to marry. Based on this stipulation, every couple, who are underage, can marry as long as they obtain their parent's consent. This practice is not considered a violation of the law; the involving parties cannot be penalized. The article argues that there is a need to review the law to prevent the practice of underage marriage.

Keywords: ambiguity, legal age of marriage, linguistics

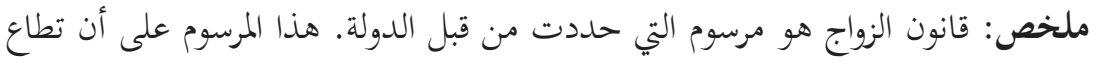

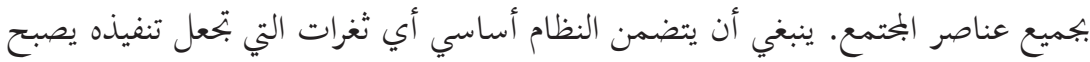

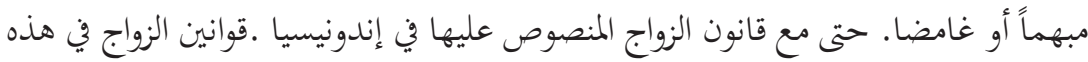

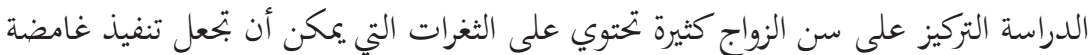

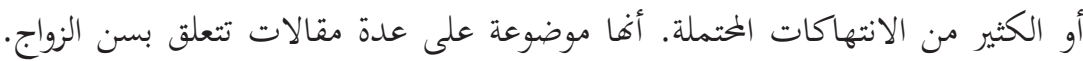

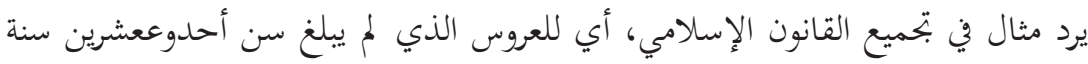

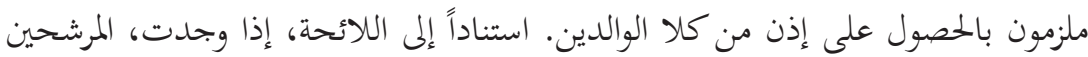

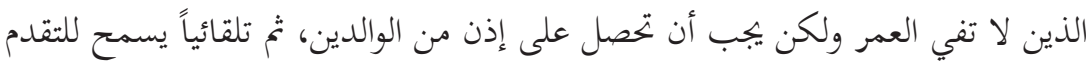

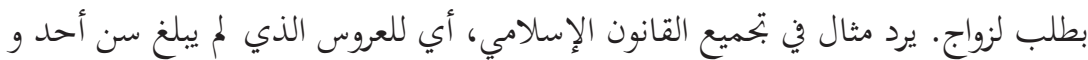

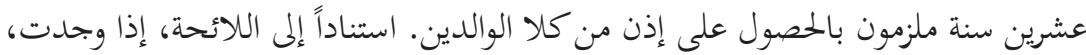

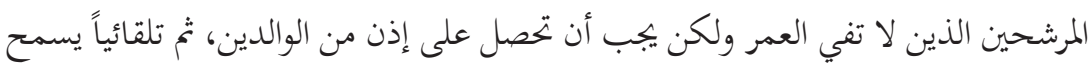

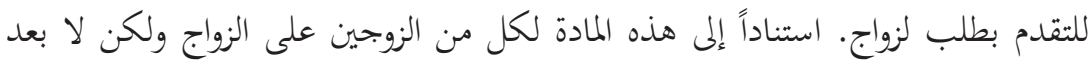

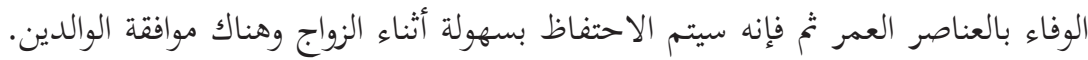

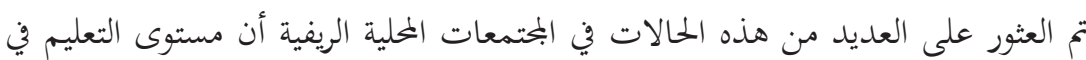

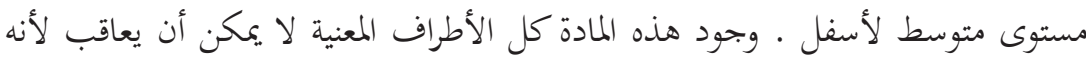

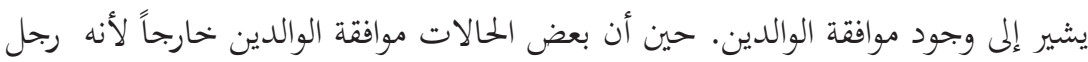

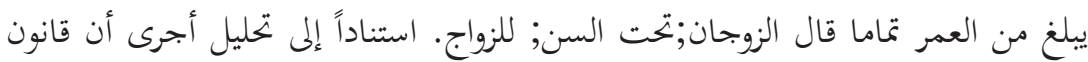

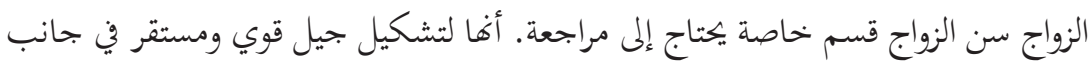
مختلفة من الحياة الكلمات المفتاحية: السن القانوين للزواج، الغموض، علم اللغة 


\section{Introduction}

Islam regulates marriage. In Indonesia, the states regulate Muslim matrimonial based on Islamic law. In Islam, ulama have a different point of view in some aspects of marriage (Hosen: 2003, 129), such as the age of marriage, the number of women to be married, marriage agreements, the number of witnesses, etc. Also, one of the characteristics of Islamic law is to change gradually depending on circumstances. The changes happen slowly in an immature society, but when the society is considered mature and aware of the importance of morality, then the 'real shari'a will guide them (Haddad: 2011, 15).

Changes in Islamic law do not occur without reasons. As in other laws, Islamic law adapts to the context in which the law applied. However, the changes should always consider the principles and guidelines of Islam. This is also applied to the law of marriage. Aspects in the law marriage need to adapt with current situation Age of marriage is one aspect that needs to be reconsidered according to the current circumstances.

Islamic law does not explicitly set the limits of the age of marriage. Qur'an and hadith do not strictly determine the age of marriage for both man and woman. With regards to the limit in the marriage age, Islam provides flexible limits so that it can be applied in all places and times (Wafa:2017,391). Even so, the age marriage is determined based on the maturity and the readiness of the bride and groom materially and spiritually.

According to the Law No. 1/1974, marriage is an inner and outer bond between a man and woman as a husband and wife, aiming at forming a happy and eternal family based on One God principle. The rationale of the implementation of marriage has indeed undergone changes from the time of the prophet Muhammad to the present. This includes the limitation of marriage age that is not precisely determined by Islam. According to Wafa, there is no age limitation for couples who want marry, and it possibly depending on views of the people (Wafa: 2017, 391). If at the time of the Prophet a marriage was carried out not only for biological purposes but also to create a relationship. From the law above, it can be understood that the purpose of marriage is to create emotional bonding. 
There have been differences in the practice of marriage, which are based on various assumptions and point of views emerged. This becomes one reason of the state's intention to unify the law and regulation on marriage. Some regulations provide detailed provision about marriage. Due to the plurality of Indonesia society regarding religions, the state has made the marriage law by considering the religious aspects of the Indonesian society. Even though the marriage law consists of some details, some matters in the law are ambiguous. This paper discusses the ambiguity in the Marriage Law, focusing on the age of marriage for both men and women.

\section{Age of Marriage in Law No.1 of 1974}

Every country has set its own rule regarding the age of marriage. The regulation is made by considering the context of each society. In Muslim countries, the provision of marriage age is based on the Islamic school of thought (madzhab) adopted by each country. The differences in the Islamic school of thought lead to the differences in the law made by each country. For example, Indonesia has applied Shafi'I school, while Egypt has applied Hanafi school. As a consequence, these two countries have different law and different kind of punishment imposed for the violation. With Hanafi School, Egypt has a stricter tendency in imposing penalties for the violation of the law.

In Indonesia, the Marriage law determines that the age of prospective grooms must be at least 18 years old, while the prospective brides must be at least 15 years old. Therefore, women who have not reached 15 years old are not allowed to make a marriage commitment themselves, unless they have essential reasons. To be allowed the need to request a dispensation from the government. For children who have not reached adulthood, they must obtain prior consent from their parents (Ramulyo:1999,60). Apart from getting consent from both parents, both prospective couple must also receive the consent statement from the Religious Court. If their application is approved, the Court will issue a marriage dispensation letter. However, if the application is rejected, the couple cannot marry. They can resubmit the application and get a marriage dispensation letter if allowed.

In determining the age of marriage, there is a need to understand the purpose of the marriage. According to Al-Ghazali, as quoted by 
Ramulyo, there are five purposes of marriage: 1) to obtain legitimate offspring to develop human race; 2) to fulfil human's instinctive demands; 3) to maintain humans from evil and damage; 4) to form and manage a family as the first base of a larger community on the basis of love and affection; 4) to grow sincerity in the attempt to meet halal livelihood and the sense of responsibility (Ramulyo:1999, 28).

Some males and females can pursue a marriage, while some others cannot. This depends on their capability. The capability is not an absolute requirement in marriage. The presence and the absence of this capability can be an initial measure to determine whether or not the objectives of a marriage can be achieved. Someone who declares his/her ability to get married means that he/she is considered to have the ability to fulfil his/ her rights and obligations within a marriage contract, either as a husband or a wife. Such capability will make the marriage work well.

The ability often becomes a requirement in marriage, depending on the prospective brides and grooms. If they are willing to be with each other without considering the 'ability' of the husband and wife, then the ability is not a valid requirement in the marriage contract. On the contrary, one of them does not want to marry with the absence of the ability; then the ability is one of the legal requirements in the marriage (Mukhtar: 1974, 39). This ability is divided into three, namely physical and spiritual skills; ability to provide income; and the ability to socialize and manage the household.

The marriage law No.1 of 1974 regulates various aspects of marriage. Chapter II of the law regulates marital conditions, which are divided into seven articles. Article 6 consists of six (6) verses detailed as follows: The marriage law No.1 of 1974 regulates all things and marriages. Chapter II of the law regulates marital conditions which are divided into seven (7) articles. Article 6 is as follows.

(1) A marriage shall be founded upon an agreement between the marriage candidates.

(2) The marriage of a person under the age of 21 years shall require the consent of both parents.

(3) When one parent has passed away or is not in a position to state his/ her will, it shall suffice that the consent referred to in paragraph

(2) be obtained of the surviving parent or of a parent who is in a 
position to state his or her will.

(4) When both parents have deceased or unable to state their will, the consent may be obtained from the guardian, the supporter or relative by consanguinity in direct ascendance, as long as such persons are still living and in a position to state their will.

(5) In the event of difference among the persons referred to in paragraphs (2), (3) and (4) of this article, or when or more of them has not made statement, the Court having jurisdiction over the domicile of the person to be married may, at the request of the latter grant approval after hearing the persons referred to in paragraph (2), (3), and (4) of this article.

(6) The provisions of paragraphs (1) through (5) of this article are applicable in so far as the laws of the respective religions and beliefs of the parties concerned do not prescribe otherwise.

Article 7 of Law No.1 of 1974 consists of three (3) articles, which are detailed as follows.

(1) A marriage is only allowed when the male candidate has reached the age of 19 years, and the female candidate has reached the age of 16 years.

(2) If a deviation from paragraph (1) of this article, dispensation may be petitioned to the Court or other authority designated by the parents of both male and female candidates.

(3) The provisions on the circumstances of one or both parents as referred to in Article 6 paragraph (3) and (4) of this Law shall be equally applicable of petitioning dispensation as referred to in paragraph (2) of this article, without prejudice to the provision in article 6 paragraph (6).

The above the law is strengthened by the Compilation of Islamic Law Book I on Marriage. Part two of the Compilation regulates the prospective couples in Article 15 as detailed below:

(1) For the benefit of the family and the household, it

The above the law is complemented by a Compilation of Islamic Law in Book I explaining Marriage. In the compilation, Part Two regulates the Bride Candidates listed in Article 15. The article can be detailed as follows. 
(1) For the benefit of the family and menage, a marriage can only be done by the candidates that have reached the age specified by the Article 7 of the Law No. 1 of 1974, which is the male candidate is at least 19 years old and the female candidate at least 16 years old.

(2) For prospective brides who have not reached the age of 21 years must obtain consent as stipulated in article 6 paragraph (2), (3), (4), and (5) Law No.1 of 1974.

\section{Ambiguity in the Marriage Law}

The above rule on marriage stated above is officially valid in Indonesia. Thus all communities should comply with these regulations. However, there are loopholes in Indonesian law that make legislation cannot be fully obeyed by the people. One of the causes of this is due to the inconsistency in the language used. Language and law are one unit. Legal language must meet the requirements and rules of the language. This is because the legal language has its special characteristics, which often difficult to be understood (Jumadi: 2016, 53). Some of the gaps make a statutory to be not maximally carried out. The nature of language is productive. This means that language can produce meanings according to the contexts (Mulyati et al.: 2014, 2.5). However, if the language is used in accordance with its function and purpose, then the language should give binding provisions for its users. For this reason, legislation is presented using the language that binds and regulates in the form of legal rules.

The loopholes in law arise in the form of sentences used and diction selections. The choice of word is important to be considered in the formulation of law. In a sociolinguistic theory, the variety of language in law falls into frozen varieties. This means that it is difficult to change the language. Frozen variety is a variation of language that is considered to be the most formal and used in solemn situations, and official ceremonies, such as state ceremonies, sermons, oaths, statutes, notary deeds, and legal decisions (Chaer and Agustin: 2010, 70). Therefore, it is necessary to think about the language before the issuance of provisions carefully.

This is also applied to the enactment of the marriage law above. The sentences and words that can confuse can be minimized or even 
eliminated. With the present of ambiguities, it is very likely the people will find it difficult to obey the law. For example, the Compilation mentions that the prospective husbands who have not reached the age of 21 should obtain consent from both parents. Based on this law, if there are candidates who have not met the age, but have gained the permission of both parents, then they are automatically allowed to marry.

In some cases, there are marriages practised by those who are still in the category of underage. These have commonly happened without any legal consequences. Often, this kind of marriages is officially recognized by the authorities. This should not happen if the law regulates and explicitly states the marriage age. With the loose law and gaps in the law caused by the language used, this violation will continue and, in this case, the government does not have any authority. The underage marriage is often related to the practice of religion. However, the government as ulil amri (leader) has an obligation and authority to regulate every practice in the society for the sake of its goodness. As such, all established law must be strictly applied, and every violation must have consequences. These consequences are also stated in the law. Laws with ambiguous gaps invite a significant potential fraud.

The Article (6) of the Marriage Law explicitly stipulates that marriage can only be carried out with the agreement of the couple, as is stated in the paragraph (1). However, even though the male and female have agreed, the government still have a regulation pertaining to the age of marriage.

The government stipulates that marriage age is limited to 21 years of age. The law is definite and firm. However, there are differences in the age of marriage by referring to Article (7) of the same law. The Article (7) of the same law states that the age of marriage for the male is at least 19 years old, while the woman is at least 16 years old. The gaps between 16 and 19 to 21 years is indeed not small. This can be seen as the inconsistency in the law. The two to five-year gap can be used to do many good things, especially in the productive age.

The determination of marriage age is ijtihad from ulama. This determination should not be too rigid so that it can be implemented according to the context. Some laws in Indonesia are stagnant due to 
its less contextual. Law is merely a display without any binding force. In the process of ijtihad, the ulama had gone through a long process of thinking and study. When the stipulation of the marriage age was presented to the government and becomes the law, it should no longer be a sought-after material. That way, the law will have its strength. By strengthening or clarifying the meaning in the Law, it is expected that the law can be implemented well and any violation can be avoided or resulted in consequences (Nuryani: 2018).

Article (6) and article (7) have no consistency. In paragraph (2) Article 6 is also ambiguous and can potentially be violated. The violation can be committed by both the children who wish to marry underage and the parents. Paragraph 2 Article (6) mentions that "to marry, a person who has not reached the age of twenty-one must get the consent from both parents". If the Article 7 indicates that the couple can marry at the age of 19 years old for men and 16 years of for women, then the Article 6 Paragraph (2) is against the provision that those who are not yet twenty years old should obtain consents from parents.

The question after that is at what age a couple is permitted to marry. If the marriage is done by a female who has not reached 19 years old and a male who has not attained 20 years old, are they required to obtain parental consent? Referring to Article 6, they are not obliged to obtain such consent, but when referring to Article 7, the should get one. This is quite troublesome for the parties who are going to marry, and also their parents.

With regards to parental consent, it also has a loophole that makes this law ambiguous. In some cases, some parents ask or "force" their children to marry at a very early age. This indeed does not violate the Marriage Law because, referring to the next paragraph, the couple, who are not old enough to marry, are permitted to do the marriage with their parents' consent. The notion of parent's consent makes the provision of underage marriage problematic because, with the parent's consent, the marriage becomes possible. Thus, the provision of marriage age does not have the power to be strictly implemented. 


\section{Conclusions}

Based on the above explanation and analysis, it can be concluded that in the marriage law, in this case, the Marriage Law No. 1 of 1974 , especially in the articles about marriage age, there are many ambiguities found. The ambiguity is found in Article 6 and Article 7. The ambiguity is also found in the Compilation of Islam Law on Marriage, which refers to the Marriage Law No. 1 of 1974. The ambiguity found can be a gap in the law and potentially lead to the fraudulent acts of law. The language used in the law is known as a 'variety of freezes' that cannot be changed by someone's will. Therefore, the law must be firm and uses a strict language. Thus, it does not lead to ambiguity and gaps so that people can violate. There is a need to review the Marriage Law, especially related to the age of marriage. People are submissive and obedient to the state law as long as it applies firmly, and consider religious aspects in it. Thus, there is no contradiction between the law and religious provisions that may cause uncertainty.

\section{References}

Chaer, Abdul dan Leoni Agustina, Sosiolinguistik: Perkenalan Awal, Jakarta: Rineka Cipta. 2010

Hosen, Ibrahim, Fiqh Perbandingan Masalah Pernikahan, Jakarta: Pustaka Firdaus, 2003.

Jumadi, "Makna Istilah dan Bahasa Hukum dalam Konteks Keadilan”, Jurnal Juresprudentie Volume 3 Nomor 1 Juni 2016

Mukhtar, Kamal, Asas-asas Hukum Islam tentang Perkawinan, Jakarta: Bulan Bintang, 1974.

Mulyati, Yeti dkk. Bahasa Indonesia. Jakarta: Universitas Terbuka.2014

Nuryani, "Pembenahan Keambiguan UU Kebahasaan demi Kekuatan Penegakkan Hukum”, Prosiding Semiloka Badan Pembinaan dan Pengembangan Bahasa, Solo, 2018

Ramulyo, Mohd. Idris, Hukum Perkawinan Islam, Jakarta: Bumi Aksara, 1999.

Undang-undang Perkawinan di Indonesia, Surabaya: Arkola.

Wafa, Moh. Ali, “Telaah Kritis terhadap Perkawinan Usia Muda menurut Hukum Islam”, Jurnal AHKAM, Volume 17, Number 2, 2017

\footnotetext{
Nuryani* \& M. Musyafa***

*Dosen di UIN Syarif Hidayatullah Jakarta

**Dosen di IAIN Fatahul Muluk Jayapura
} 


\section{Mhliam}

AHKAM Jurnal Ilmu Syariah (ISSN: 1412-4734/E-ISSN: 2407-8646) is a periodical scientific journal published by Faculty of Sharia and Law of Syarif Hidayatullah State Islamic University Jakarta in collaboration with Indonesian Scientist and Sharia Scholar Association (HISSI). This journal specifically examines the science of sharia and obtains to present various results of current and eminence scientific research. The administrators receive articles as contributions Sharia and Islamic law disciplines from scientists, scholars, professionals, and researchers to be published and disseminated. The article will be situated in a selection mechanism, a review of proved reders, and a strict editing process. All articles published in this Journal are based on the views of the authors, but they do not represent the authors' journals or affiliated institutions.

AHKAM has been accredited based on the determination of Director General of Research Reinforcement and Development, Research, and Technology Ministry of Higher Education of Republic of Indonesia, No. 36/a/E/KPT/2016 (valid until 2021). 